\title{
Characterization of the Bacillus subtilis Penicillin-Binding Protein PBP4*
}

\author{
Arnaud Vanden Broeck ${ }^{1}$ (), Eric Sauvage ${ }^{2}$, Bernard Joris ${ }^{1 \#, ~ C o l e t t e ~ D u e z ~}{ }^{1 \# ~(1) ~}$ \\ ${ }^{1}$ Institut de Chimie, Centre for Protein Engineering, University of Liège, Liège, Belgium \\ ${ }^{2}$ Institut de Physique, Centre for Protein Engineering, University of Liège, Liège, Belgium \\ Email: "bjoris@uliege.be, "cduez@uliege.be
}

How to cite this paper: Vanden Broeck, A., Sauvage, E., Joris, B. and Duez, C. (2019) Characterization of the Bacillus subtilis Penicillin-Binding Protein PBP4*. Advances in Microbiology, 9, 164-176. https://doi.org/10.4236/aim.2019.93013

Received: January 23, 2019

Accepted: March 2, 2019

Published: March 5, 2019

Copyright (c) 2019 by author(s) and Scientific Research Publishing Inc. This work is licensed under the Creative Commons Attribution International License (CC BY 4.0).

http://creativecommons.org/licenses/by/4.0/

(c) (i) Open Access

\begin{abstract}
Purpose: The $\mathrm{PBP} 4^{*}$ is a Penicillin Binding Protein belonging to the class $\mathrm{C}$ of AmpH type whose function remains poorly understood. This study aimed to evaluate the biophysical and enzymatic properties of the Bacillus subtilis $\mathrm{PBP}^{*}$ to gain insights into its role in the context of bacterial cell wall recycling. Methods: To characterize the $\mathrm{PBP}^{*}$, the full-length $\mathrm{PBP}^{*}$ and its $\mathrm{N}$-terminal penicillin-binding domain have been produced in Escherichia coli and purified. Results: A comparison of biophysical properties has shown that both recombinant proteins are monomeric in solution and retain the same thermal stability. On the other hand, the D-alanine methyl esterase activity detected with the full-length $\mathrm{PBP}^{*}$ is impeded by the cleavage of the 92 amino acid C-terminal domain. The esterase activity of the full-length PBP4* demonstrates a clear D-stereospecificity. The $\mathrm{PBP} 4^{*}$ is also active on $B$. subtilis cell walls bearing teichoic acids, compounds commonly substituted with $\mathrm{D}$-alanine residues. Conclusions: Our results are in agreement with the hypothesis that $\mathrm{PBP}^{*}{ }^{*}$ could play a role in recycling cell wall components, as previously suggested.
\end{abstract}

\section{Keywords}

B. subtilis PBP4*, Class-C PBP, D-Stereospecific Esterase

\section{Introduction}

The genome of Bacillus subtilis contains many genes coding for PenicillinBinding Proteins (PBPs) including $p b p E$ which is translated into $\mathrm{PBP} 4^{*}$, a protein of 451 amino acids (NCBI accession number: CCD10845). The PBP4* belongs to the class $\mathrm{C}$ of $\mathrm{AmpH}$ type and its function and cellular role remain poorly understood. This PBP is composed of a $\mathrm{N}$-terminal domain which har- 
bors the three highly conserved motifs characteristic of PBPs $\left(\mathrm{S}^{61} \mathrm{LSK}^{64}, \mathrm{Y}^{153} \mathrm{SN}^{155}\right.$ and $\mathrm{H}^{302} \mathrm{SG}^{304}$ ) and is related to the Ochrobactrum anthropi D-aminopeptidase. The 92 amino acid C-terminal domain (CTD) consists of a predicted lipocalin-like fold of unknown function. At downstream of $p b p E$, there is a second gene named $\mathrm{rac} X$ since its product presents sequence similarity with aspartate or glutamate racemases. The two genes constitute an operon and are parts of the $\sigma^{\mathrm{W}}$ regulon. Popham and Setlow [1] have purified multiple PBPs from B. subtilis membranes by penicillin affinity chromatography. The $\mathrm{N}$-terminal sequence of an apparent $56 \mathrm{kDa}$ protein was identified as the beginning of the $p b p E \mathrm{ORF}$, indicating that its product, named $\mathrm{PBP} 4^{*}$, is not processed. This observation is in agreement with the absence of a predicted signal peptide in the $\mathrm{PBP}^{*}$ sequence. The purification method indicates that the $\mathrm{PBP} 4^{*}$ is associated with the cytoplasmic membrane. The $p b p E$ gene is weakly expressed during the phase of vegetative growth; however its expression is induced upon entrance into the phase of stationary growth [1]. Partial or complete deletion of the pbpE-racX operon neither resulted in a particular phenotype (at least in growth on rich or minimal media) nor in differences in heat resistance and germination rates of spores, invalidating the hypothesis that $\mathrm{PBP} 4^{\star}$ is a sporulation-specific gene [2]. Using a chromogenic cephalosporin, Popham and Setlow have detected a weak $\beta$-lactamase activity in a B. subtilis wild-type preparation in contrast to that from the $p b p E$ mutant strain [1]. The authors also conducted $\mathrm{D}$-aminopeptidase activity assays with $\mathrm{D}$-alanine- $p$-nitroanilide substrate but obtained negative results. They proposed a role for $\mathrm{PBP} 4^{*}$ and RacX in the recycling of peptidoglycan components, a process especially important under starvation conditions [1].

The expression of $p b p E$ is enhanced in response of $B$. subtilis to different stresses. The extracytoplasmic RNA polymerase $\sigma^{\mathrm{W}}$ factor activates genes involved in the antimicrobial resistance mechanisms, in the synthesis or secretion of bacteriocins and genes expressed in response to antibiotics that interfere with the biosynthesis and/or in proper functioning of the cell wall (e.g. vancomycin, cephalosporin and D-cycloserine). A role in detoxifying the cell has been proposed for the genes of the $y c e C$ operon, $y b f O, y d j P$, $y f h M$ and $p b p E$ [3] [4] [5] [6]. Experiments aiming to identify $B$. subtilis genes induced by a sudden increase in the external $\mathrm{pH}$ (from $\mathrm{pH} 6.3$ to 8.9 ) revealed the induction of more than 80 genes including $p b p E$ and $r a c X$ [7] [8]. The $\mathrm{PBP}^{*}$ is also listed among the proteins induced by ammonium starvation, mainly during the transition to the phase of stationary growth [9]. Other studies [10] [11] have shown that $p b p E$ was overexpressed in response to high salt stress, suggesting that PBP4* could play a role in the cell wall rearrangements that take place during the osmoadaptation of B. subtilis. Interestingly, a zymogram analysis demonstrated that PBP4 has a hydrolysis activity on cell walls [11]. Furthermore, a strain in which $p b p E$ has been disrupted presents a salt-sensitive phenotype and an increased sensitivity to cell envelope active antibiotics (vancomycin, penicillin and bacitracin) [11]. However, neither precise structural modifications of the cell wall are elucidated nor is the specific contribution of $\mathrm{PBP} 4^{\star}$ to these modifications. 
B. subtilis overproducing $\mathrm{PBP} 4^{*}$ has a filamentous phenotype. In the absence of the FtsH metalloprotease, an upregulation of the whole $\sigma^{\mathrm{W}}$ regulon is observed, as well as an enhanced transcription of $p b p E$, causing an accumulation of $\mathrm{PBP}^{*}$ in $B$. subtilis. The inactivation of both $f t s H$ and $p b p E$ restored the wild-type cell morphology, indicating that the accumulation of $\mathrm{PBP}^{*}$ is responsible for the filamentous phenotype [12]. The way this phenotype is induced by $\mathrm{PBP} 4{ }^{\star}$ remains unclear.

The localization of the Green Fluorescent Protein fused to PBP4* has been monitored [13]. During the phase of vegetative growth, GFP-PBP4* localized in a punctuated pattern along the bacterial rod, similar to those observed with most PBPs [14].

To gain knowledge on the B. subtilis $\mathrm{PBP}^{*}$ role, we have purified the full-length protein and its $\mathrm{N}$-terminal domain $\left(\mathrm{PBP} 4^{\star} \Delta \mathrm{CTD}\right)$ and performed biophysical and enzymatic characterizations.

\section{Material and Methods}

\subsection{Cloning Strategies and Plasmids}

The pJet1.2/blunt vector (Thermo Scientific) was used to clone the fragments amplified by PCR and to verify their sequences (GIGA sequencing platform, University of Liège, Belgium). The pET28-MHL plasmid (Addgene) was used as expression vector to produce the entire $\mathrm{PBP} 4^{\star}$ or its $\mathrm{N}$-terminal domain (PBP4* $\triangle \mathrm{CTD}$ ) in fusion with a N-terminal 18 amino acid peptide containing six histidine residues followed by a TEV protease cleavage site. In the pET28-MHL plasmid, the translation initiation codon is present in an NdeI restriction site (CATATG). Silent mutations were introduced in $p b p E$ to suppress two internal NdeI restriction sites using the following strategy: three fragments of $p b p E$ were amplified from the B. subtilis ATCC21332 genomic DNA with the Q5 High Fidelity DNA polymerase (Bioke). The first fragment (5' portion of the gene) was obtained with the primers pbpE_frag1_fw and pbpE_frag1_mut1_rev. The second fragment corresponding to the central part of the gene was amplified with the primers pbpE_frag2_mut1_fw and pbpE_frag2_mut2_rev and the third fragment ( 3 ' portion of the gene) was obtained with the oligonucleotides pbpE_frag3_mut2_fw and pbpE_frag3_rev. The external primers pbpE_frag1_fw and pbpE_frag3_rev contain an NdeI or XhoI restriction site respectively. The internal oligonucleotides form two pairs of primers with complementary sequences and a single modified nucleotide in the NdeI restriction sites. A final PCR using the mixture of the three fragments as templates and the primers pbpE_frag1_fw and pbpE_frag3_rev allowed to amplify the entire $p b p E$ gene without internal NdeI restriction sites. The $1.4 \mathrm{~kb}$ PCR product was cloned into the pJet1.2/blunt vector and the insert sequence was completely verified. The modified $p b p E$ gene was cloned into pET28-MHL yielding the pET28-MHL-pbpE plasmid. The $\mathrm{PBP} 4^{\star} \triangle \mathrm{CTD}$ coding sequence (comprising the first 359 residues) was amplified from the pET28-MHL-pbpE plasmid with the pbpENterm-fw and pbpENterm-rev primers. After verification of its sequence, the fragment was 
cloned into the pET28-MHL vector yielding the pET28-pbpENterm plasmid. The sequences of the primers are reported in (Table 1).

\subsection{Production of PBP4* and PBP4* $\triangle \mathrm{CTD}$}

E. coli Nico21 (DE3) competent cells (New England Biolabs) were transformed with the pET28-MHL-pbpE or pET28-MHL-pbpENterm plasmids. Bacterial cells were grown in two litres of Terrific Broth medium at $37^{\circ} \mathrm{C}$ until an $\mathrm{OD}_{600 \mathrm{~nm}}$ of 1.2 and induced with $1 \mathrm{mM}$ IPTG. After 4 hours at $37^{\circ} \mathrm{C}$, the cells were collected by centrifugation at $7000 \mathrm{~g}$ for $20 \mathrm{~min}$. The pellet was resuspended in 80 $\mathrm{mL}$ of $25 \mathrm{mM}$ HEPES $\mathrm{pH} 7.5,100 \mathrm{mM} \mathrm{NaCl}, 5 \mathrm{mM} \mathrm{MgCl}_{2}$, and $1 \mathrm{mM}$ PMSF. After addition of $200 \mathrm{U}$ benzonase (Novagen), the cells were broken in a high-pressure homogenizer (Emulsiflex $\mathrm{C} 3$, Avestin Europe $\mathrm{GmbH}$ ) and debris and intact cells were eliminated by centrifugation at 25,000 g for $30 \mathrm{~min}$. The His-tagged $\mathrm{PBP}^{*}{ }^{*}$ or $\mathrm{PBP} 4^{*} \triangle \mathrm{CTD}$ were purified using the Profinia ${ }^{\mathrm{Tm}}$ Affinity Chromatography Protein Purification System (Biorad). The equilibration, washing and elution buffers were supplemented with 5, 10 and $250 \mathrm{mM}$ imidazole respectively. The purified proteins were eluted in desalting buffer $(25 \mathrm{mM}$ HEPES $\mathrm{pH} 7.5, \mathrm{NaCl} 100 \mathrm{mM}$ ) with a yield of $63 \mathrm{mg}$ of full-length PBP4* and 50 $\mathrm{mg}$ of PBP4* $\triangle \mathrm{CTD}$.

\subsection{Cleavage of the $\mathrm{N}$-Terminal Sequence with the TEV Protease}

In order to cleave the $\mathrm{N}$-terminal extension containing the polyhistidine sequence, the purified $\mathrm{PBP} 4^{*}$ and $\mathrm{PBP} 4^{*} \triangle \mathrm{CTD}$ were incubated overnight at $4^{\circ} \mathrm{C}$ with TEV protease (TEV-recombinant proteins mass ratio 1:50) in $25 \mathrm{mM}$ HEPES $\mathrm{pH} 7.5,100 \mathrm{mM} \mathrm{NaCl}$. The cleavage efficiency was verified by SDS-PAGE analysis and the mixture loaded on Ni-NTA agarose to retain the N-terminal peptide. A mass spectrometry measurement (CART-LSM GIGA University of Liège, Belgium) and the $\mathrm{N}$-terminal sequencing by Edman degradation confirmed the complete

Table 1. Names and sequences of primers used for suppressing the $p b p E$ internal NdeI restriction sites and for cloning the full-length $\mathrm{PBP} 4^{*}$ or PBP4* $\triangle \mathrm{CTD}$ coding sequences into the pET28-MHL expression plasmid. The sequences in bold (CATATG and CTCGAG) correspond to a NdeI and XhoI restriction site respectively. The underlined nucleotides indicate the silent mutations introduced in internal NdeI restriction sites.

\begin{tabular}{cl}
\hline Primer name & \multicolumn{1}{c}{ Sequence (5' to $3^{\prime}$ ) } \\
\hline pbpE_frag1_fw & GCGCATATGAAACAGAATAAAAGAAAGCATCTTCAGACA \\
pbpE_frag1_mut1_rev & GTACATCATACACATATCCATA__GCATAATGATCA \\
pbpE_frag2_mut1_fw & TGATCATTATGCTTATGGATATGTGTATGATGTAC \\
pbpE_frag2_mut2_rev & GGGACCTCATAA_GGCTGGCCAAATA \\
pbpE_frag3_mut2_fw & TATTTGGCCAGCCTTATGAGGTCCC \\
pbpE_frag3_rev & ACAACTCGAGATTAATTTGTACGGACCGCTTCTTCTTCT \\
pbpENterm-fw & GCGCATATGAAACAGAATAAAAGAAAGCATCTTC \\
pbpENterm-rev & ACAACTCGAGATTAAGCAGGACGTTCCGGG \\
\hline
\end{tabular}


elimination of the $\mathrm{N}$-terminal extension leaving only two additional amino acids (Gly and His) before the native sequence of the purified proteins (Figure 1(a)).

\subsection{Thermal Denaturation Assay}

Thermal denaturation analyses of PBP4* and its N-terminal domain (PBP4* $\triangle \mathrm{CTD}$ ) were performed by DSF (Differential Scanning Fluorimetry) using the Prometheus NT.48 (NanoTemper Technologies), a capillary-based instrument measuring microscale thermophoresis. The NanoDSF technology detects very small changes in the fluorescence of tryptophan and tyrosine present in the protein without needing any dye. Experiments were performed as following: protein samples were buffer exchanged against $25 \mathrm{mM}$ HEPES pH 8.0, $100 \mathrm{mM} \mathrm{NaCl}$ using Micro Bio-Spin P6 columns (BioRad) and diluted at $30 \mu \mathrm{M}$ in the same buffer. Ten $\mu \mathrm{L}$ of each sample were injected in a thin capillary (provided with the Prometheus NT48 system) and submitted to a $20^{\circ} \mathrm{C}-95^{\circ} \mathrm{C}$ temperature gradient with a $1^{\circ} \mathrm{min}^{-1}$ increase rate. The first derivatives of the sigmoid curves provide fusion temperatures $(\mathrm{Tm})$ of the proteins, corresponding to the denaturation midpoint. Experiments were performed 3 times for both proteins.

\subsection{Dynamic Light Scattering}

Dynamic light scattering (DLS) measurements were carried out in $25 \mathrm{mM}$ HEPES pH 8.0, $100 \mathrm{mM} \mathrm{NaCl}$ using a DynaPro NanoStar ${ }^{\mathrm{TM}}$ (Wyatt Technologies, $100 \mathrm{~mW}$ He-Ne laser, $\lambda_{0}=658 \mathrm{~nm}, \theta=90^{\circ}$ ) spectrophotometer. DLS experiments were performed at $15^{\circ} \mathrm{C}$ in disposable Uvette ${ }^{\mathrm{TM}}$ cells (Eppendorf) filled

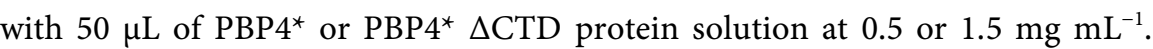
Measurements, corresponding to 10 readings of 5 seconds, were taken three times with a pause of 5 minutes between them to provide means and square deviations of the parameters. Scattering intensities were analyzed using the Dynamics software (Wyatt Technologies) to calculate the hydrodynamic diameters (Dh), the polydispersity indexes and to estimate the molecular weights.

\subsection{Size-Exclusion Chromatography}

Proteins were loaded on a Superdex S200 10/300 column (GE Healthcare) preequilibrated in $25 \mathrm{mM}$ HEPES pH 8, $100 \mathrm{mM} \mathrm{NaCl}$ to determine their elution volumes and calculate their apparent masses based on a calibration curve (BioRad).

\subsection{Enzyme Assays}

\subsubsection{DD-Carboxypeptidase Activity}

DD-carboxypeptidase activity was assayed with benzoyl-D-alanyl thioacetyl ester (S2d) as substrate [15]. A sample $(150 \mu \mathrm{L})$ containing $3 \mu \mathrm{g} \mathrm{PBP} 4^{*}, 1 \mathrm{mM} \mathrm{S} 2 \mathrm{~d}$ and 1 mM DTNB in $50 \mathrm{mM}$ HEPES pH 7 and a blank without enzyme were incubated at room temperature for $20 \mathrm{~min}$. The absorbance values were monitored at $412 \mathrm{~nm}$.

\subsubsection{Aminopeptidase Activity}

Aminopeptidase activity was tested on L or D-amino acids fused to a $\operatorname{para}(p) n$ - 
itroanilide (NA) group. L- and D-Ala- $p \mathrm{NA}, \mathrm{L}$ - and D-Glu- $p \mathrm{NA}$, L-Met- $p \mathrm{NA}, \mathrm{L}-$ and D-Phe- $p$ NA and L-Pro- $p$ NA (Sigma-Aldrich) have been used. Samples (100 $\mu \mathrm{L})$ containing $500 \mu \mathrm{M}$ of putative substrate and $50 \mu \mathrm{g} \mathrm{PBP} 4^{*}$ in $25 \mathrm{mM}$ HEPES $\mathrm{pH} 7.5,100 \mathrm{mM} \mathrm{NaCl}$ were incubated at $37^{\circ} \mathrm{C}$ for 2 hours. A blank without enzyme allows to determine if the yellow colour is due to the aminopeptidase activity of PBP4*.

\subsubsection{Esterase Activity}

Esterase activity was tested on D-Alanine methyl ester (D-Ala $\mathrm{OMe}$ ) hydrochloride (Bachem) or DL-Alanine methyl ester hydrochloride (Sigma-Aldrich) as substrates. The assays were all performed at $24^{\circ} \mathrm{C}$ in $50 \mathrm{mM}$ HEPES pH 7.5, $5 \mathrm{mM}$ $\mathrm{MgCl}_{2}$. In these conditions of temperature and $\mathrm{pH}$, the spontaneous hydrolysis of the substrate is less than $2 \%$. Samples $(40 \mu \mathrm{L})$ containing $1-7 \mathrm{mM} \mathrm{D}$-Ala OMe and $4.65 \mu \mathrm{M}$ full-length $\mathrm{PBP} 4^{*}$ or the substrate alone were incubated for 15 - $30 \mathrm{~min}$ and then transferred on ice. The amounts of D-Alanine resulting from the enzymatic activity or from the substrate instability were measured using the D-Amino Acid Oxidase (DAAO) method [16]. Absorbance values of standards containing 0 - 30 nmoles D-Alanine yielded a straight line that allowed to calculate the esterase activity associated with PBP4*.

The initial rates $\left(\mathrm{v}_{0}\right)$ were fitted to the Henri-Michaelis-Menten equation using a nonlinear regression analysis with the help of the GraphPad Prism 5.04 software. The kinetic constants were also determined with the Hanes plot in which the $S / \mathrm{v}_{0}$ ratios are plotted versus the substrate $[\mathrm{S}]$ concentrations, which gave a straight line that allowed to calculate the $K_{m}$ and $K_{m} / V_{\max }$ ratio.

\subsubsection{Determination of the Substrate Stereospecificity of PBP4*}

Samples $(40 \mu \mathrm{L})$ containing $4.65 \mu \mathrm{M}$ of full-length $\mathrm{PBP}^{*}$ and $20 \mathrm{mM}$ of racemic DL-Ala OMe substrate or the substrate alone were prepared in duplicates, incubated for $30 \mathrm{~min}$ and then transferred on ice. After addition of a second reaction mixture containing either $50 \mathrm{U}$ DAAO or $12 \mathrm{U}$ LAAO (L-Amino Acid Oxidase from the Crotalus adamanteus venom, Sigma-Aldrich), the samples were incubated at $37^{\circ} \mathrm{C}$ for 15 or 30 min respectively. Absorbance values of standards containing 0 - 40 nmoles L-Alanine fit to a straight line in the LAAO test.

\subsubsection{Enzyme Assay on Bacillus subtilis Cell Walls}

Suspensions $\left(2 \times 100 \mu \mathrm{L}\right.$ at $\left.10 \mathrm{mg} \mathrm{mL}^{-1}\right)$ of cell walls bearing teichoic acids were rinsed three times with $50 \mathrm{mM}$ HEPES $\mathrm{pH} 7.5$ and resuspended in the same buffer at the initial concentration. One sample constituted a blank while the other one was supplemented with $10 \mu \mathrm{gBP} 4^{*}$. Both samples were incubated at $24^{\circ} \mathrm{C}$ for 16 hours. After centrifugation (at 14,000 $\mathrm{g}$ for $10 \mathrm{~min}$ ) the possible release of $\mathrm{D}$-alanine residues in the supernatants was quantified using the DAAO method.

\section{Results and Discussion}

The B. subtilis $\mathrm{PBP}^{*}$ produced in E. coli as a recombinant protein of 453 resi- 
dues or its $\mathrm{N}$-terminal domain (PBP4* $\triangle \mathrm{CTD}$ ) lacking the 92 last residues

(Figure 1(a)-lanes II and IV) were used in all experiments.

\subsection{Physical Characterizations of the Full-Length PBP4* and Its N-Terminal Domain PBP4* $\triangle$ CTD}

The thermal denaturation curves indicated that the $\mathrm{T}_{\mathrm{m}}$ temperatures of $\mathrm{PBP} 4^{*}$ and $\mathrm{PBP} 4^{\star} \triangle \mathrm{CTD}$ are $59^{\circ} \mathrm{C} \pm 0.3^{\circ} \mathrm{C}$ and $60^{\circ} \mathrm{C} \pm 0.2^{\circ} \mathrm{C}$ respectively (Figure $1(\mathrm{~b})$ ).

(a)

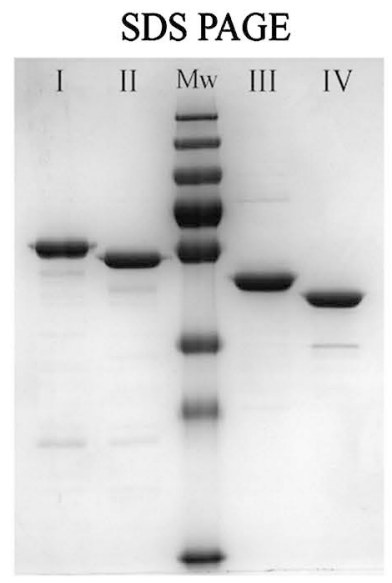

(b)

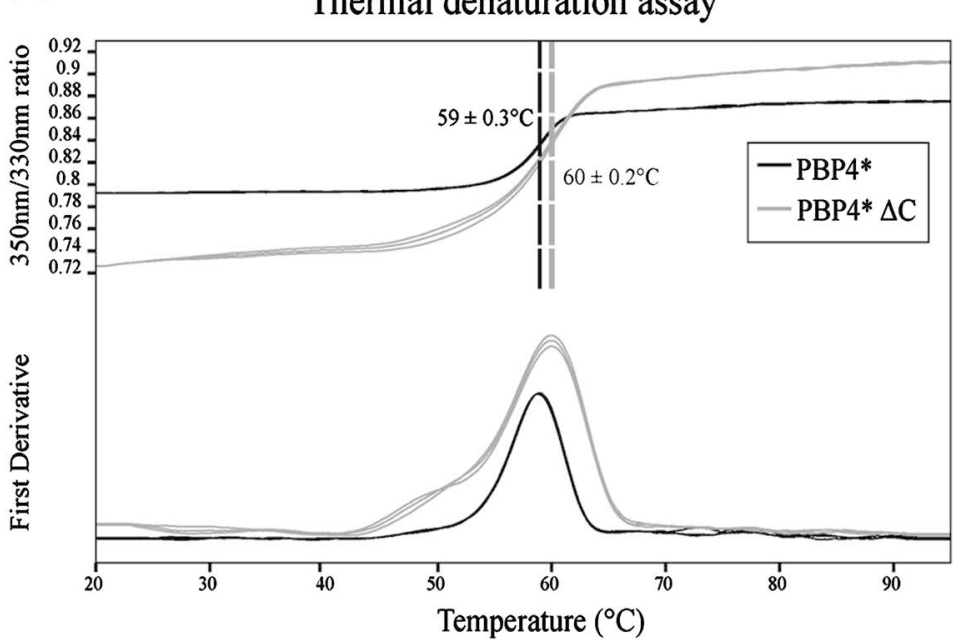

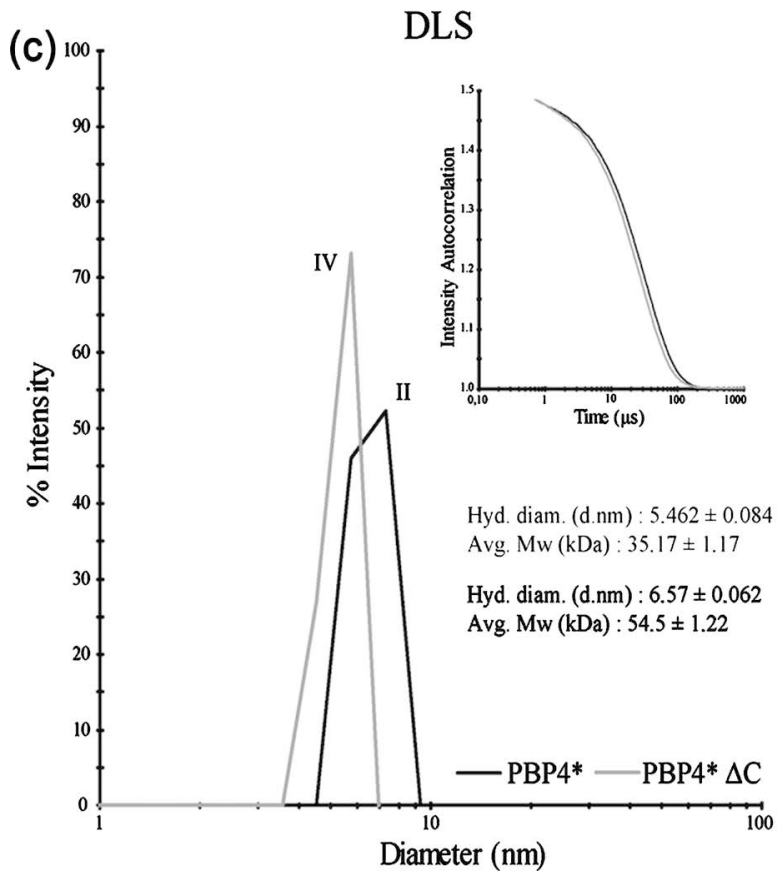

(d)

Exclusion chromatography

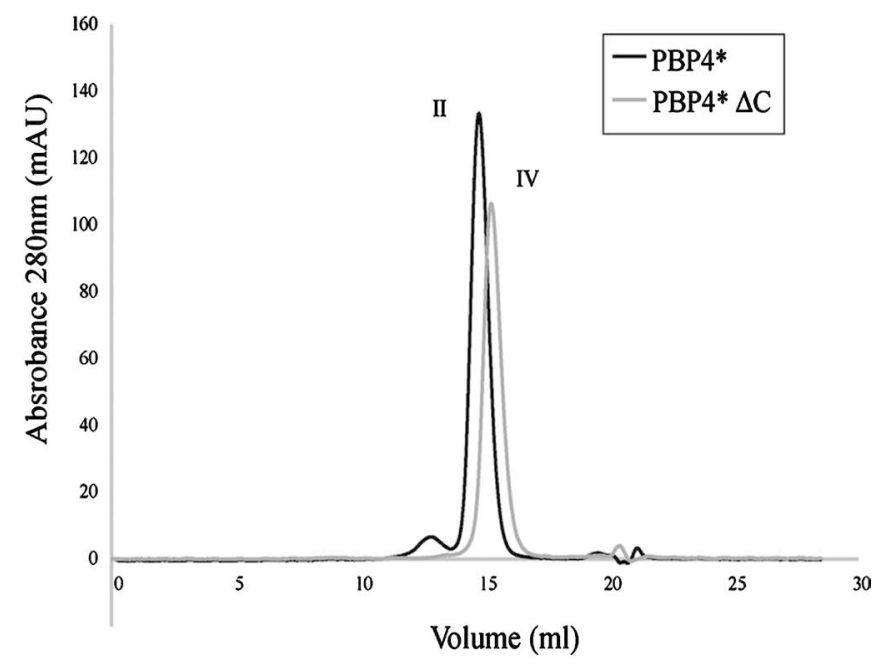

Figure 1. Biophysicals characterizations of the full-length PBP4 $4^{\star}$ and its N-terminal domain (PBP4* $\triangle \mathrm{CTD}$ ). (a) SDS-PAGE analysis on a $12 \%$ acrylamide gel of $\mathrm{PBP} 4^{\star}$ and $\mathrm{PBP} 4^{\star} \triangle \mathrm{CTD}$ before and after treatment with the TEV protease. Lane I: PBP4 ${ }^{\star}$ with a $\mathrm{N}$-terminal tag, lane II: PBP4* after TEV cleavage, lane III: PBP4* $\triangle$ CTD with a N-terminal tag, lane IV: PBP4* $\Delta$ CTD after TEV cleavage. (b) Thermal denaturation analyses of PBP4* and its $\mathrm{N}$-terminal domain (PBP4* $\Delta \mathrm{CTD}$ ). The curves from three experiments are presented and the data were treated with the PR control software (NanoTemper Technologies). (c) Dynamic Light Scattering profiles of $\mathrm{PBP} 4^{\star}$ and $\mathrm{PBP} 4^{\star} \triangle \mathrm{CTD}$. The intensity autocorrelation curves are shown as an inset. (d) Size-exclusion chromatography profiles of $\mathrm{PBP} 4^{\star}$ and $\mathrm{PBP} 4^{\star} \Delta \mathrm{CTD}$. 
Deletion of the C-terminal domain did not show a significant impact on the thermal stability of PBP4* ${ }^{*}$ The results of Dynamic Light Scattering experiments performed on $\mathrm{PBP} 4^{*}$ and $\mathrm{PBP} 4^{*} \triangle \mathrm{CTD}$ have shown that both proteins are monomeric in solution, with estimated masses $(\mathrm{kDa})$ of $54.5 \pm 1.22$ and $35.17 \pm 1.17$ respectively (Figure $1(\mathrm{c})$ ). Compared to the $\mathrm{PBP} 4^{*} \triangle \mathrm{CTD}$, the diffusion properties of the full-length $\mathrm{PBP} 4^{*}$ were slowed and relaxation of the autocorrelation was longer. The profiles of exclusion size chromatography of $\mathrm{PBP} 4^{\star}$ and $\mathrm{PBP} 4^{\star}$ $\triangle \mathrm{CTD}$ were also those of monomeric proteins, with estimated masses $(\mathrm{kDa})$ of 55.97 and 45.37 respectively (Figure $1(\mathrm{~d})$ ). All the results are summarized in (Table 2).

\subsection{Enzymatic Characterization of the Full Length PBP4*}

\subsubsection{DD-Carboxypeptidase Activity}

The full-length PBP4* exhibits a specific activity of $0.12 \mu \mathrm{mol} \cdot \mathrm{min}^{-1} \cdot \mathrm{mg}^{-1}$ on the S2d substrate. In comparison, the $B$. subtilis $\mathrm{PBP} 4 \mathrm{a}$ used in the same conditions as a control, hydrolysed S2d with a 60-fold higher specific activity [17].

\subsubsection{Aminopeptidase Activity}

All the tested compounds gave negative results even after an overnight incubation at $37^{\circ} \mathrm{C}$.

\subsubsection{Esterase Activity}

The full-length $\mathrm{PBP} 4^{\star}$ did efficiently cleave the D-Ala methyl ester and the kinetic parameters have been determined (Figure 2 and Figure 3 ). The $K_{m}$ values calculated with the GraphPad Prism 5.04 software or using the Hanes plot were 2.24 and $2.5 \mathrm{mM}$ respectively.

According to the method used for calculating the parameters, the enzyme turnover $\left(k_{c a t}\right)$ given by the $V / E_{0}$ ratio ( $E_{0}$ being the enzyme molarity in the assay) was comprised between 129 and $133 \mathrm{~s}^{-1}$ yielding $K_{c a t} / K_{m}$ ratios of 58 and 53 $\mathrm{mM}^{-1} \cdot \mathrm{s}^{-1}$ respectively. The $V_{\max }$ values of the $\mathrm{PBP} 4^{*}$ with this substrate were comprised between 0.6 to $0.62 \mathrm{mM}^{-1} \cdot \mathrm{s}^{-1}$. Surprisingly, the esterase activity of the N-terminal domain (PBP4* $\triangle$ CTD) was only $20 \%$ of that obtained with the full-length $\mathrm{PBP} 4^{*}$, indicating that the C-terminal domain is important for the hydrolysis of D-Ala methyl ester.

\subsubsection{Determination of the Substrate Stereospecificity of PBP4*}

To know if the full-length $\mathrm{PBP} 4^{\star}$ hydrolyses only the substrate in the D conformation, the racemic DL-Ala OMe substrate was used at the final concentrations of $10 \mathrm{mM}$ for each form (a concentration corresponding to 4-fold the $K_{m}$ value determined with the pure $\mathrm{D}$-substrate) and the release of $\mathrm{D}$ - or L-alanine was quantified using the DAAO or LAAO enzymes. The small amounts of L-alanine measured in the blank or in the sample were equal and it appeared clearly that only the $\mathrm{D}$ conformation of the substrate was recognized and hydrolyzed. The $\mathrm{PBP}^{*}$ esterase activity is therefore D-stereospecific. Since teichoic acids attached to the peptidoglycan of Gram positive bacteria are partly substituted with 
Table 2. Conditions and results of biophysical characterizations of the B. subtilis PBP4* and $\mathrm{PBP} 4^{*} \triangle \mathrm{CTD}$.

\begin{tabular}{|c|c|c|}
\hline Thermal Denaturation Assay & & \\
\hline Instrument & \multicolumn{2}{|c|}{ Prometheus NT48 (Nano Temper) } \\
\hline Employed software & \multicolumn{2}{|c|}{ PR. control (NanoTemper) } \\
\hline Wavelength (nm) & \multicolumn{2}{|c|}{ ratio $350-330$} \\
\hline Temperature gradient $\left({ }^{\circ} \mathrm{C}\right)$ & \multicolumn{2}{|c|}{$20-95$} \\
\hline Heating rate $\left({ }^{\circ} \mathrm{C} \min ^{-1}\right)$ & \multicolumn{2}{|c|}{1} \\
\hline Protein sample & PBP4* $^{*}$ & $\mathrm{PBP}^{*} \Delta \mathrm{CTD}$ \\
\hline Concentration $(\mu \mathrm{M})$ & 30 & 30 \\
\hline Buffer condition & \multicolumn{2}{|c|}{25 mM HEPES, 100 mM NaCl, pH 8.0} \\
\hline Volume $(\mu \mathrm{L})$ & 10 & 10 \\
\hline \multicolumn{3}{|l|}{$\underline{\text { Results }}$} \\
\hline Fusion temperature $\operatorname{Tm}\left({ }^{\circ} \mathrm{C}\right)$ & $59^{\circ} \mathrm{C} \pm 0.3^{\circ} \mathrm{C}$ & $60^{\circ} \mathrm{C} \pm 0.2^{\circ} \mathrm{C}$ \\
\hline \multicolumn{3}{|l|}{ Dynamic Light Scattering Assay } \\
\hline Instrument & \multicolumn{2}{|c|}{ DynaPro NanoStarTM (Wyatt Technologies) } \\
\hline Employed software & \multicolumn{2}{|c|}{ Dynamics 7.1.9. (Wyatt Technology) } \\
\hline Laser & \multicolumn{2}{|c|}{$100 \mathrm{~mW} \mathrm{He}-\mathrm{Ne}$} \\
\hline Wavelength (nm) & \multicolumn{2}{|c|}{658} \\
\hline Angle $\left({ }^{\circ}\right)$ & \multicolumn{2}{|c|}{90} \\
\hline Exposure time (sec) & \multicolumn{2}{|c|}{$50(10$ frames $\times 5 \mathrm{sec})$} \\
\hline Protein sample & $\mathrm{PBP}^{*}$ & $\mathrm{PBP}^{*} \Delta \mathrm{CTD}$ \\
\hline Concentration $(\mu \mathrm{M})$ & 30 & 30 \\
\hline Buffer condition & \multicolumn{2}{|c|}{25 mM HEPES, 100 mM NaCl, pH 8.0} \\
\hline Temperature $\left({ }^{\circ} \mathrm{C}\right)$ & 10 & 10 \\
\hline Volume $(\mu \mathrm{L})$ & 50 & 50 \\
\hline \multicolumn{3}{|l|}{$\underline{\text { Results }}$} \\
\hline Hydrodynamic diameter (nm) & $6.57 \pm 0.062$ & $5.462 \pm 0.084$ \\
\hline Polydispersity index (PDI) & $0.016 \pm 0.004$ & $0.009 \pm 0.002$ \\
\hline Estimated molecular weight $(\mathrm{kDa})$ & $54.5 \pm 1.22$ & $35.17 \pm 1.17$ \\
\hline \multicolumn{3}{|l|}{ Exclusion Chromatography } \\
\hline Column & \multicolumn{2}{|c|}{ Superdex S200 10/30 GL (GE Healthcare) } \\
\hline Instrument & \multicolumn{2}{|c|}{ Åkta Purifier (GE Healthcare) } \\
\hline Employed software & \multicolumn{2}{|c|}{ Unicorn (GE Healthcare Life Sciences) } \\
\hline Wavelength (nm) & \multicolumn{2}{|c|}{280} \\
\hline Flow $\left(\mathrm{mL} \min ^{-1}\right)$ & \multicolumn{2}{|c|}{0.5} \\
\hline Injection loop volume $(\mu \mathrm{L})$ & \multicolumn{2}{|c|}{100} \\
\hline Protein sample & PBP4* $^{*}$ & $\mathrm{PBP}^{*} \Delta \mathrm{CTD}$ \\
\hline Injected mass $(\mu \mathrm{g})$ & 100 & 100 \\
\hline
\end{tabular}




\section{Continued}

\begin{tabular}{|c|c|c|}
\hline Buffer condition & \multicolumn{2}{|c|}{25 mM HEPES, 100 mM NaCl, pH 8.0} \\
\hline Temperature $\left({ }^{\circ} \mathrm{C}\right)$ & 4 & 4 \\
\hline \multicolumn{3}{|l|}{$\underline{\text { Results }}$} \\
\hline Elution volume $(\mathrm{mL})$ & 14.75 & 15.24 \\
\hline Estimated mass $(\mathrm{kDa})$ & 55.97 & 45.37 \\
\hline \multicolumn{3}{|l|}{ Mass Determination } \\
\hline Protein sample & PBP4* $^{*}$ & $\mathrm{PBP}^{*} \Delta \mathrm{CTD}$ \\
\hline $\begin{array}{c}\text { Calculated monomeric mass }(\mathrm{kDa}) \text { (from the } \\
\text { sequence, using Expasy software) }\end{array}$ & $\sim 51$ & $\sim 41$ \\
\hline Mass (kDa) (from DLS) & $54.5 \pm 1.22$ & $35.17 \pm 1.17$ \\
\hline $\begin{array}{l}\text { Mass }(\mathrm{kDa}) \text { (from size-exclusion } \\
\text { chromatography) }\end{array}$ & 55.97 & 45.37 \\
\hline Oligomeric state in solution & Monomeric & Monomeric \\
\hline
\end{tabular}

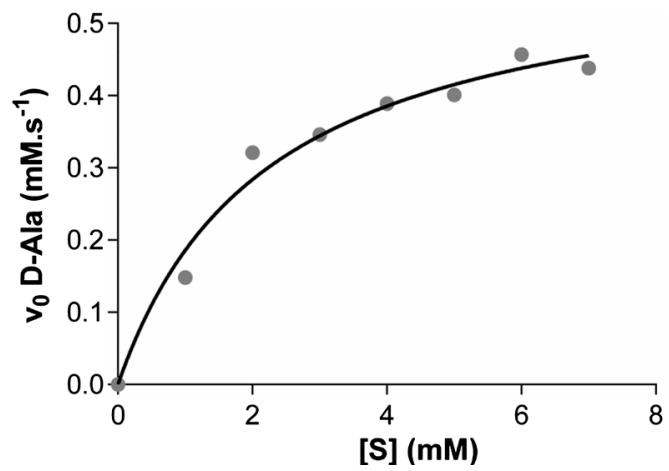

Figure 2. Initial rates $\left(v_{0}\right)$ of the $\mathrm{PBP} 4^{*}$ esterase activity in function of the D-Ala methyl ester substrate $[\mathrm{S}]$ concentrations. After subtraction of the values given by a blank without enzyme to deduce the spontaneous hydrolysis of the substrate, the graph presents the initial rates of D-Ala methyl ester hydrolysis by the PBP4* in $\mathrm{mM} \cdot \mathrm{s}^{-1}$. In all cases, the values of substrate hydrolysis by the enzyme was less than $20 \%$.

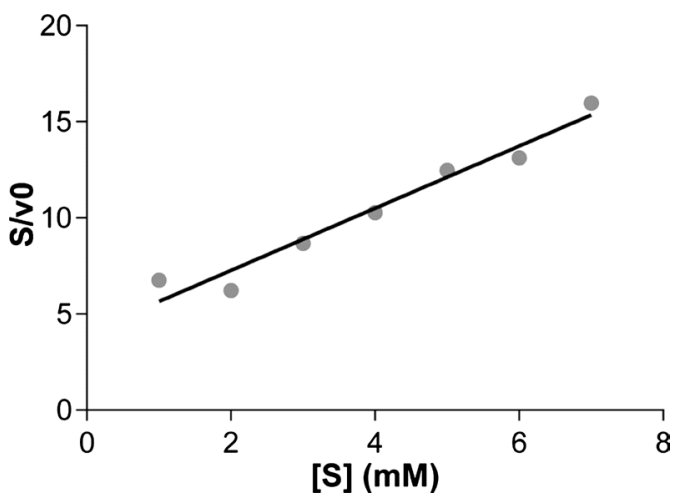

Figure 3. Hanes plot. The $\mathrm{mM}$ concentrations of D-Ala methyl ester used as substrate [S] to determine the initial rates $\left(V_{0}\right)$ of the $\mathrm{PBP}^{*}$ esterase activity are indicated on the $\mathrm{x}$ axis. The ratio $S / V_{0}$ of hydrolysis ( $\mathrm{mM}$ freed D-Ala $\mathrm{s}^{-1}$ ) is indicated on the y axis. Equation of the linear interpolation is $y=1.616 x+4.037$ with $\mathrm{R}^{2}=0.957$. The intercept value with the ordinate (4.037) corresponds to the $K_{m} / \mathrm{V}$ ratio and the one with the $\mathrm{x}$ axis $(-2.5)$ to $-K_{m}$. The calculated $V_{\max }$ value of D-Ala methyl ester hydrolysis by the full length $\mathrm{PBP}^{*}$ is $0.62 \mathrm{mM} \cdot \mathrm{s}^{-1}$. 
glucose and D-alanine, it was tempting to search for an esterase activity of the full length $\mathrm{PBP} 4^{*}$ on these compounds. Indeed, the $\mathrm{PBP} 4^{*}$ is active on suspensions of B. subtilis cell walls bearing teichoic acids [18] and after subtraction of the amount of $\mathrm{D}$-alanine measured in the blank, 6.2 nmoles of $\mathrm{D}$-alanine were found to be released from $1 \mathrm{mg}$ of cell walls in the conditions described in Material and Methods.

\section{Conclusion}

The entire B. subtilis $\mathrm{PBP}^{\star}$ has been produced in E. coli as a recombinant protein of 453 residues after successful cleavage of the $\mathrm{N}$-terminal extension. To detect a possible influence of the $\mathrm{C}$-terminal domain (comprising 92 residues) on the folding, stability or enzymatic activity of $\mathrm{PBP} 4^{*}$, the recombinant $\mathrm{N}$-terminal (PBP) domain of 361 residues was also produced (Figure 1(a)) and some properties of both proteins have been characterized and compared (Table 2 ). The thermal stability of the full length $\mathrm{PBP}^{*}$ protein was not significantly modified by the C-terminal domain deletion (Figure 1(b)). The results of Dynamic Light Scattering experiments (Figure 1(c)) and the size-exclusion chromatography profiles of $\mathrm{PBP} 4^{*}$ and $\mathrm{PBP} 4^{*} \triangle \mathrm{CTD}$ (Figure $1(\mathrm{~d})$ ) indicated that both proteins are monomeric in solution, excluding a possible oligomerization of the protein harboring the C-terminal extension. For the first time, a clear esterase enzymatic activity has been detected with the full length PBP4* and the kinetic parameters have been determined (Figure 2 and Figure 3). This activity was D-stereospecific and was significantly lower with the protein lacking the C-terminal domain. A possible role of the C-terminal extension could be its participation in the productive positioning of the substrate in the enzymatic cleft. Structural data should provide information about this hypothesis. The full length PBP4* was also active on B. subtilis cell walls containing teichoic acids but however this result does not mean that teichoic acids are physiological substrates for the native PBP4*. This protein has been shown to be associated with the cytoplasmic membrane [1]. To influence the amount of D-alanine-substituted teichoic acids and thus their net charge, the active site of $\mathrm{PBP}^{*}$ must be located on the outer face of the cytoplasmic membrane. How the PBP4* is embedded into the membrane remains to elucidate. Such an esterase activity is compatible with a role for the $\mathrm{PBP} 4^{*}$ in recycling cell wall components as previously proposed [1].

\section{Acknowledgements}

We are grateful to Nicole Otthiers for the N-terminal sequencing of PBP4*, to Astrid Zervosen for the enzymatic assay on the S2d substrate, to Philippe Margot for the gift of Bacillus subtilis cell walls and to Jean-Marie Frère for critical reading.

\section{Funding}

This work was supported by the Belgian Programm on Interuniversity Poles of 
Attraction by the Prime Minister's Office, Science Policy Programming (IAP P7/44). The funders had no role in study design, data analyses, decision to publish or preparation of the manuscript. Colette Duez was Research Associate of the Fonds National de la Recherche scientifique FRS-FNRS, Brussels, Belgium.

\section{Conflicts of Interest}

The authors declare that no competing interests exist.

\section{References}

[1] Popham, D.L. and Setlow, P. (1993) Cloning, Nucleotide Sequence, and Regulation of the Bacillus subtilis pbpE Operon, Which Codes for Penicillin-Binding Protein $4^{*}$ and an Apparent Amino Acid Racemase. Journal of bacteriology, 175, 2917-2925. https://doi.org/10.1128/jb.175.10.2917-2925.1993

[2] Sowell, M.O. and Buchanan, C.E. (1983) Changes in Penicillin-Binding Proteins during Sporulation of Bacillus subtilis. Journal of Bacteriology, 153, 1331-1337.

[3] Cao, M., Kobel, A., Morshedi, M.M. and Wu, M.F. (2002) Defining the Bacillus subtilis $\sigma^{\mathrm{W}}$ Regulon: A Comparative Analysis of Promoter Consensus Search, Run-Off Transcription/Macroarray Analysis (ROMA), and Transcriptional Profiling Approaches. Journal of Molecular Biology, 316, 443-457. https://doi.org/10.1006/jmbi.2001.5372

[4] Cao, M., Wang, T., Ye, R. and Helmann, J.D. (2002) Antibiotics That Inhibit Cell Wall Biosynthesis Induce Expression of the Bacillus subtilis $\sigma^{\mathrm{W}}$ and $\sigma^{\mathrm{M}}$ Regulons. Molecular Microbiology, 45, 1267-1276. https://doi.org/10.1046/j.1365-2958.2002.03050.x

[5] Butcher, B.G. and Helmann, J.D. (2006) Identification of Bacillus subtilis $\sigma^{\mathrm{W}}$-Dependent Genes That Provide Intrinsic Resistance to Antimicrobial Compounds Produced by Bacilli. Molecular Microbiology, 60, 765-782. https://doi.org/10.1111/j.1365-2958.2006.05131.x

[6] Jordan, S., Hutchings, M.I. and Mascher, T. (2008) Cell Envelope Stress Response in Gram-Positive Bacteria. FEMS Microbiology Reviews, 32, 107-146. https://doi.org/10.1111/j.1574-6976.2007.00091.x

[7] Wiegert, T., Homuth, G., Versteeg, S. and Schumann, W. (2001) Alkaline Shock Induces the Bacillus subtilis $\sigma^{\mathrm{W}}$ Regulon. Molecular Microbiology, 41, 59-71. https://doi.org/10.1046/j.1365-2958.2001.02489.x

[8] Heinrich, J. and Wiegert, T. (2006) YpdC Determines Site-1 Degradation in Regulated Intramembrane Proteolysis of the RsiW Anti-Sigma Factor of Bacillus subtilis. Molecular Microbiology, 62, 566-579. https://doi.org/10.1111/j.1365-2958.2006.05391.x

[9] Tam, L.T., Antelmann, H., Eymann, C., Albrecht, D., Bernhardt, J. and Hecker, M. (2006) Proteome Signatures for Stress and Starvation in Bacillus subtilis as Revealed by a 2-D Gel Image Color Coding Approach. Proteomics, 6, 4565-4585. https://doi.org/10.1002/pmic.200600100

[10] Hahne, H., Mäder, U., Otto, A., Bonn, F., Steil, L., Bremer, E., Hecker, M. and Becher, D. (2010) A Comprehensive Proteomics and Transcriptomics Analysis of Bacillus subtilis Salt Stress Adaptation. Journal of Bacteriology, 192, 870-882. https://doi.org/10.1128/JB.01106-09

[11] Palomino, M.M., Sanchez-Rivas, C. and Ruzal, S.M. (2009) High Salt Stress in Bacillus subtilis. Involvement of PBP4* as a Peptidoglycan Hydrolase. Research in Mi- 
crobiology, 160, 117-124. https://doi.org/10.1016/j.resmic.2008.10.011

[12] Zellmeier, S., Zuber, U., Schumann, W. and Wiegert, T. (2003) The Absence of FtsH Metalloprotease Activity Causes Overexpression of the $\sigma^{\mathrm{W}}$-Controlled $p b p E$ Gene, Resulting in Filamentous Growth of Bacillus subtilis. Journal of Bacteriology, 185, 973-982. https://doi.org/10.1128/JB.185.3.973-982.2003

[13] Scheffers, D.-J. (2005) Dynamic Localization of Penicillin-Binding Proteins during Spore Development in Bacillus subtilis. Microbiology, 151, 999-1012. https://doi.org/10.1099/mic.0.27692-0

[14] Scheffers, D.-J., Jones, L.J. and Errington, J. (2003) Several Distinct Localization Patterns for Penicillin-Binding Proteins in Bacillus subtilis. Molecular Microbiolo$g y$, 51, 749-764. https://doi.org/10.1046/j.1365-2958.2003.03854.x

[15] Adam, M., Damblon, C., Jamin, M., Zorzi, W., Dusart, V., Galleni, M., El Kharroubi, A., Piras, G., Spratt, B.G. and Keck, W. (1991) Acyltransferase Activities of the High-Molecular-Mass Essential Penicillin-Binding Proteins. Biochemical Journal, 279, 601-604. https://doi.org/10.1042/bj2790601

[16] Frère, J.-M., Leyh-Bouille, M., Ghuysen, J.-M., Nieto, M. and Perkins, H.R. (1976) Exocellular DD-Carboxypeptidases-Transpeptidases from Streptomyces. Methods in Enzymology, 45, 610-636. https://doi.org/10.1016/S0076-6879(76)45054-1

[17] Duez, C., Vanhove, M., Gallet, X., Bouillenne, F., Docquier, J.-D., Brans, A. and Frère, J.-M. (2001) Purification and Characterization of PBP4a, a New Low-Molecular-Weight Penicillin-Binding Protein from Bacillus subtilis. Journal of Bacteriology, 183, 1595-1599. https://doi.org/10.1128/JB.183.5.1595-1599.2001

[18] Margot, P. and Karamata, D. (1996) The wprA Gene of Bacillus subtilis 168, Expressed during Exponential Growth, Encodes a Cell-Wall-Associated Protease. $\mathrm{Mi}$ crobiology, 142, 3437-3444. https://doi.org/10.1099/13500872-142-12-3437 